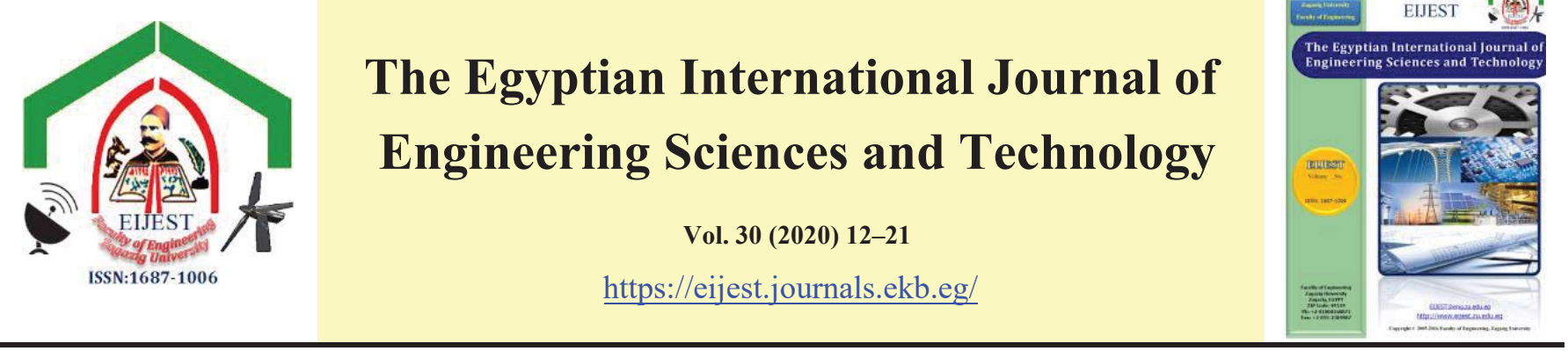

\title{
Improving Compressive strength of Lightweight Aggregate Concrete
}

\begin{tabular}{|c|c|}
\hline A R T I CLE I NFO & A B S T R A C T \\
\hline $\begin{array}{l}\text { Keywords: } \\
\text { 1. Lightweight Aggregate } \\
\text { Concrete. } \\
\text { 2. Lightweight Aggregate. } \\
\text { 3. Crushed Sand Brick. } \\
\text { 4. Expanded Polystyrene. }\end{array}$ & $\begin{array}{l}\text { This work aims to improve the strength of Lightweight Aggregate Concrete } \\
\text { (LWAC) developed in Egypt using available local materials. The Crushed } \\
\text { Sand Brick (CSB) was used with ( } 50,60 \text {, and } 70 \text { percent) replacement ratios } \\
\text { of crushed dolomite by volume in two options, once without surface coating } \\
\text { another time after coating its surface with cement mortar before mixing. It is } \\
\text { recommended to use uncoated CSB with a replacement ratio of } 60 \text { percent } \\
\text { which provided optimum compressive strength/density ratio. Expanded } \\
\text { Polystyrene (EP) was cut manually and used with of } 60 \% \text { replacement ratio of } \\
\text { crushed dolomite by volume by study the effect of type of Lightweight } \\
\text { Aggregate (LWA) on properties and strength of LWAC, finally Expanded } \\
\text { Polystyrene Granules (EPG) with particle size less than } 4.75 \text { mm was used as } \\
60 \% \text { replacement of sand by volume. Cement content was increased from } 350 \\
\mathrm{Kg} / \mathrm{m}^{3} \text { to } 450 \mathrm{Kg} / \mathrm{m}^{3} \text {, Silica Fume (SF) was added with different doses (10, } 20 \text {, } \\
\text { and } 30 \text { ) } \% \text { of cement by weight, and High Range Water Reducer (HRWR) was } \\
\text { used with different doses }(2,3 \text {, and } 4) \% \text { of binder materials by weight to } \\
\text { improve compressive strength and properties of LWAC. The type of LWA } \\
\text { was found to be the most effective factor on the strength of LWAC. }\end{array}$ \\
\hline
\end{tabular}

\section{Introduction}

LWAC is a type of concrete that depends on partial or total replacement of the normal weight aggregate with LWA causing extreme reduction in mechanical properties than normal weight concrete, unit weight of LWAC varies from 1500 to 2000 $\mathrm{kg} / \mathrm{m}^{3}$, and compressive strengths also varies from 10 to $21 \mathrm{MPa}$ [1], variation of LWAC properties is related to properties of materials used in its production [2], smaller sections can be obtained for structural elements. LWA may be also used as insulating fill[3], LWAC has a degree of durability[4], the elasticity modulus of LWA and matrix is approximately equivalent resulting in extreme reduction in stress concentration at the aggregate matrix interface compared to normal weight concrete [5].Several factors affect properties of LWAC such as type and properties of used LWA and its content in the mix, water to cement ratio, cement content, and used additives, water absorption of LWA isn't the only factor affecting mixing water absorption but also its moisture content [6],using LWA instead of normal weight aggregate causes reduction in strength and stiffness of LWAC [7], the thermal insulation efficiency depends significantly on the thermal conductivity of LWA [8], higher concrete durability can be achieved when LWA is replaced with normal weight sand[9], durability against physical attack is related to LWA type [10], using air-

\footnotetext{
* Corresponding author.

E-mail address: zezookhaled010@gmail.com
} 
entraining agent cause reduction in density of LWAC [11], LWAC using EP has higher strength, less unit weight, and lower thermal conductivity than that produced with vermiculite[12], initial curing and its duration hasa greater effect on durability comparing with its effect on compressive strength [13], the compressive strength of EP concretes with fly ash can gradually increase over 90 [14], strength and durability of LWAC can be increased by using silica fume[15],compressive strength and elasticity modulus are improved by $57 \%$ and $14 \%$ respectively when introducing $5-15 \%$ silica fume of cement content by weight in case of LWAC [16], structural applications of LWAC could be enhanced as it met the requirements of code of practice [17].

\section{Methods and Experimental Program}

\subsection{Materials}

Properties of Concrete Raw Materials are shown in Table 1 all results were obtained experimentally, CSB was weighed without coating, another time it was immersed in cement mortar then it was extracted to dry for one day and then it was weighed.

Table 1. Properties of Concrete Raw Materials

\begin{tabular}{|c|c|c|c|}
\hline $\begin{array}{c}\text { Property } \\
\text { Material }\end{array}$ & $\begin{array}{c}\text { Specific } \\
\text { Gravity }\end{array}$ & $\begin{array}{c}\text { Unit Weight } \\
\left(\mathrm{Kg} / \mathrm{m}^{3}\right)\end{array}$ & $\begin{array}{c}\text { Absorption } \\
\text { Ratio (\%) }\end{array}$ \\
\hline $\begin{array}{c}\text { Crushed } \\
\text { Dolomite }\end{array}$ & 2.67 & 1770 & 1.5 \\
\hline Sand & 2.53 & 1774 & 1.5 \\
\hline CSB & .898 & 396 & 69.8 \\
\hline $\begin{array}{c}\text { CSB after surface } \\
\text { coating with } \\
\text { cement mortar }\end{array}$ & 1.81 & 1043 & 4.8 \\
\hline EP & .011 & 17.33 & 1 \\
\hline Cement & 3.15 & - & - \\
\hline Silica Fume & 2.15 & - & - \\
\hline HRWR & 1.15 & - & - \\
\hline
\end{tabular}

\subsection{EXPERIMENTAL METHOD}

The experimental program was planned to improve the compressive strength of LWAC, firstly normal weight concrete mix (A)was cast without additives, secondly LWAC mixes were cast using CSB as a partial replacement of crushed dolomite by volume with differentratios (50, 60, and 70 percent) in two options firstly without surface coating for Mixes (B, C, and D) respectively as shown in Table 2 , another time for coated surface CSB with cement mortar before mixing with the same volumetric replacement ratios for Mixes (E, F, and $\mathrm{G}$ ) respectively as shown in Table 3. According to the results of unit weight and compressive strength of LWAC mixes it's recommended to use uncoated CSB with $60 \%$ replacement ratio of crushed dolomite by volume as it gave the optimum compressive strength to density ratio comparing with 50 and $70 \%$ replacement ratios.

In order to improve the compressive strength of LWAC, cement content was increased, chemical and mineral admixtures were also introduced.

Table 2. Mix Design for normal weight concrete and lightweight aggregate concrete using uncoated crushed sand brick

\begin{tabular}{|c|c|c|c|c|}
\hline Mix Id & A & B & C & D \\
\hline Weight of Cement(Kg) & 350 & 350 & 350 & 350 \\
\hline Weight of Sand (Kg) & 740 & 645 & 645 & 645 \\
\hline $\begin{array}{c}\text { Weight of Dolomite } \\
(\mathrm{Kg})\end{array}$ & 1163 & 506 & 405 & 304 \\
\hline $\begin{array}{c}\text { Weight of Crushed } \\
\text { Sand Brick (Kg) }\end{array}$ & 0 & 172 & 206 & 240 \\
\hline Weight of Water (Kg) & 175 & 252 & 252 & 252 \\
\hline
\end{tabular}

Table 3. Mix design for lightweight aggregate concrete using crushed sand brick coated with cement mortar.

\begin{tabular}{|c|c|c|c|}
\hline Mix Id & E & F & G \\
\hline Weight of Cement (Kg) & 350 & 350 & 350 \\
\hline Weight of Sand (Kg) & 715 & 715 & 715 \\
\hline $\begin{array}{c}\text { Weight of Dolomite } \\
(\mathrm{Kg})\end{array}$ & 562 & 450 & 337 \\
\hline $\begin{array}{c}\text { Weight of Crushed Sand } \\
\text { Brick (Kg) }\end{array}$ & 384 & 461 & 537 \\
\hline Water Content (Kg) & 182 & 182 & 182 \\
\hline
\end{tabular}

Cement content was increased as following 350, 400 , and $450 \mathrm{Kg} / \mathrm{m}^{3}$ for mixes $(\mathrm{C}, \mathrm{H}$, andI) respectively as shown in Table 4.

Table 4. Mix design for lightweight aggregate concrete using uncoated crushed sand brick by increasing cement content

\begin{tabular}{|c|c|c|}
\hline Mix Id & H & I \\
\hline Material & 400 & 450 \\
\hline Weight of Cement(Kg) of Sand(Kg) & 592 & 540 \\
\hline Weight of Crushed Dolomite $(\mathrm{Kg})$ & 372 & 339 \\
\hline Weight of Crushed Sand Brick (Kg) & 189 & 172 \\
\hline Water Content (Kg) & 288 & 324 \\
\hline
\end{tabular}

HRWR was used with different doses $(2,3$, and 4) $\%$ of binder materials by weight for mixes (J, K, and L) respectively, finally silica fume was added with different doses $(10,20$, and 30) \% of cement by weight for mixes ( $\mathrm{M}, \mathrm{N}$, and $\mathrm{T}$ ) respectively, as shown in Table 5. 
Table 5. Mix design for lightweight aggregate concrete using uncoated crushed sand brick with additives

\begin{tabular}{|c|c|c|c|c|c|c|}
\hline Mix Id & $\mathrm{J}$ & $\mathrm{K}$ & $\mathrm{L}$ & $\mathrm{M}$ & $\mathrm{N}$ & $\mathrm{T}$ \\
\hline $\begin{array}{c}\text { Material } \\
\text { Cement }\end{array}$ & 450 & 450 & 450 & 405 & 360 & 315 \\
\hline $\begin{array}{c}\text { Content } \\
\text { (Kg) }\end{array}$ & 600 & 646 & 683 & 654 & 624 & 595 \\
\hline $\begin{array}{c}\text { Wt of } \\
\text { Sand (Kg) }\end{array}$ & 377 & 508 & 429 & 410 & 393 & 374 \\
\hline $\begin{array}{c}\text { Wt of } \\
\text { Crushed } \\
\text { Dolomite } \\
\text { (Kg) }\end{array}$ & 191 & 173 & 218 & 210 & 200 & 190 \\
\hline $\begin{array}{c}\text { Wt of } \\
\text { Crushed } \\
\text { sand Brick } \\
\text { (Kg) }\end{array}$ & 0 & 0 & 0 & 45 & 90 & 135 \\
\hline $\begin{array}{c}\text { Water } \\
\text { Content } \\
\text { (Kg) }\end{array}$ & 257 & 207 & 167 & 189 & 212 & 234 \\
\hline $\begin{array}{c}\text { Silica Fume } \\
\text { Content } \\
\text { (Kg) }\end{array}$ & 0 & 18 & 18 & 18 & 18 \\
\hline $\begin{array}{c}\text { High range } \\
\text { water } \\
\text { reducer } \\
\text { Content } \\
\text { (Kg) }\end{array}$ & 9 & 14 & & & \\
\hline
\end{tabular}

EP was also used in two options once it was cut manually with size greater than $4.75 \mathrm{~mm}$ and used with $60 \%$ replacement ratio of crushed dolomite by volume with cement contents 350 , and $450 \mathrm{Kg} / \mathrm{m}^{3}$ for mixes $\mathrm{P}$ and $\mathrm{Q}$ respectively another time with size smaller than $4.75 \mathrm{~mm}$ and used as $60 \%$ replacement of sand by volume for mixes $\mathrm{W}$ and $\mathrm{X}$ respectively as shown in Table6.

Table 6. Mix design for lightweight aggregate concrete using Expanded Polystyrene with increasing cement content

\begin{tabular}{|c|c|c|c|c|}
\hline Mix Id & P & Q & W & X \\
\hline Weight of Cement(Kg) & 350 & 450 & 350 & 450 \\
\hline Weight of Sand(Kg) & 740 & 662 & 296 & 265 \\
\hline $\begin{array}{c}\text { Weight of Crushed } \\
\text { Dolomite (Kg) }\end{array}$ & 465 & 416 & 1162 & 1041 \\
\hline $\begin{array}{c}\text { Weight ofExpanded } \\
\text { Polystyrene (Kg) }\end{array}$ & 3 & 3 & 2 & 2 \\
\hline Water Content $(\mathrm{Kg})$ & 158 & 203 & 158 & 203 \\
\hline
\end{tabular}

According to EP as coarse LWA (2\%) HRWR of binder materials by weight was used as in mix (R), and $20 \%$ silica fume of cement by weight was also used as in $\operatorname{mix}(\mathrm{S})$.In case of EP as fine LWA (2\%) HRWR of binder materials by weight was used as in mix (Y), and $20 \%$ silica fume of cement by weight was also used as in mix (Z) as shown in Table 7.

All concrete mixes were designed according to absolute volume method.

Table 7. Mix design for lightweight aggregate concrete using expanded polystyrene with additives

\begin{tabular}{|c|c|c|c|c|}
\hline Mix Id & $\mathrm{R}$ & $\mathrm{S}$ & $\mathrm{Y}$ & $\mathrm{Z}$ \\
\hline Material & 450 & 360 & 450 & 360 \\
\hline Weight of Cement(Kg) & 700 & 695 & 282 & 267 \\
\hline Weight of Sand(Kg) & 440 & 437 & 1106 & 1049 \\
\hline $\begin{array}{c}\text { Weight of Crushed } \\
\text { Dolomite (Kg) }\end{array}$ & 3 & 3 & 2 & 2 \\
\hline $\begin{array}{c}\text { Weight of Expanded } \\
\text { Polystyrene (Kg) }\end{array}$ & 158 & 144 & 158 & 180 \\
\hline $\begin{array}{c}\text { Weight of Water(Kg) } \\
\text { Wt of Silica Fume (Kg) }\end{array}$ & 0 & 90 & 0 & 90 \\
\hline $\begin{array}{c}\text { High Range Water Reducer } \\
\text { Content (Kg) }\end{array}$ & 9 & 9 & 9 & 9 \\
\hline
\end{tabular}

\section{Results and Discussion}

Tables and figures of the experimental data which exhibits the effect of the various parameters on (W/C) ratio, unit weight, and compressive strength will be discussed as following.

\subsection{Effect of Different Parameters on Water to Cement Ratio}

\subsubsection{Effect of Aggregate Type on (W/C) Ratio}

That effect is shown in Table 8 and figure 1. Normal weight concrete made with crushed dolomite and sand possessed a water to cement ratio of 0.50 , while using LWA caused extreme increase in $(\mathrm{W} / \mathrm{C})$ ratio, whereas LWAC using uncoated CSB presented in mix $(\mathrm{C})$ indicates $(\mathrm{W} / \mathrm{C})$ ratio of 0.72 , and 0.52 when using CSB coated with cement mortar as in mix (F).

$0.50(\mathrm{~W} / \mathrm{C})$ ratio was used for LWAC using EP as coarse LWA presented in mix (P) and for LWAC using EPG as fine LWA presented in mix (W). 
Table 8 . Effect of aggregate type on $(\mathrm{W} / \mathrm{C})$ ratio

\begin{tabular}{|c|c|c|}
\hline $\begin{array}{c}\text { Mix } \\
\text { Id }\end{array}$ & $\begin{array}{c}(\text { W/C) Ratio } \\
\%\end{array}$ & $\begin{array}{c}\text { (W/C) Ratio of the Mix Relative to } \\
\text { Mix (A) } \%\end{array}$ \\
\hline A & 0.50 & 100 \\
\hline C & 0.72 & 144 \\
\hline F & 0.52 & 104 \\
\hline P & 0.50 & 100 \\
\hline W & 0.50 & 100 \\
\hline
\end{tabular}

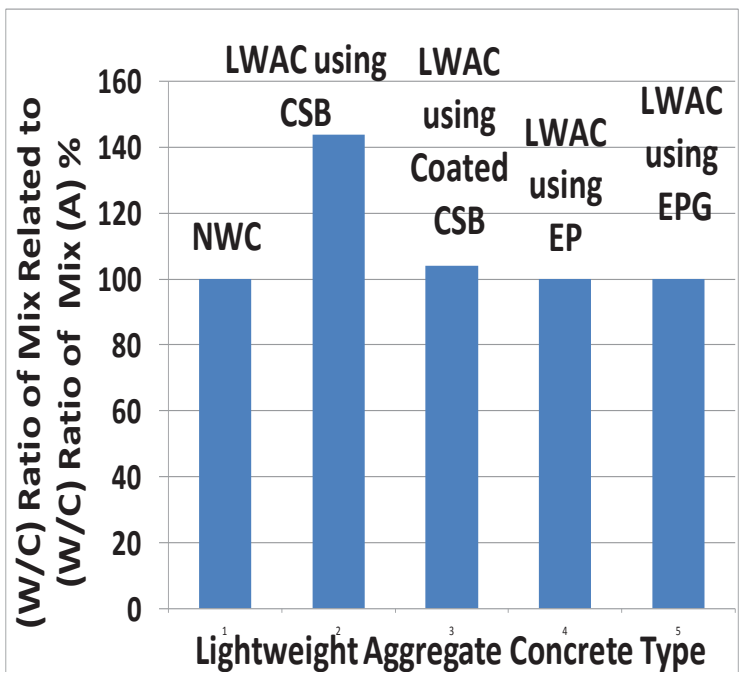

Fig 1 Effect of aggregate type on (W/C) Ratio

\subsubsection{Effect of HRWR on (W/C) Ratio}

That effect is shown in Table 9 and figure 2. The (W/C) ratio of LWAC using uncoated CSB changes according to the dose of HRWR, whereas 57, 46 and $37 \%(\mathrm{~W} / \mathrm{C})$ ratios have been indicated for 2,3 and $4 \%$ HRWR of binder materials by weight as presented in mixes $\mathrm{J}, \mathrm{K}$, and $\mathrm{L}$ respectively, $2 \%$ HRWR of binder by weight reduces (W/C) ratio from 0.50 to 0.35 for both LWAC using EP as coarse LWA and for LWAC using EPG as fine LWA presented in mixes $\mathrm{R}$ and $\mathrm{Y}$ respectively.

Table 9. Effect of HRWR on (W/C) Ratio

\begin{tabular}{|c|c|c|c|}
\hline $\begin{array}{c}\text { Mix } \\
\text { ID }\end{array}$ & $\begin{array}{c}\text { \% of } \\
\text { HRWR }\end{array}$ & $\begin{array}{c}\text { (W/C) } \\
\text { Ratio } \%\end{array}$ & $\begin{array}{c}\text { (W/C) Ratio of the Mix } \\
\text { Relative to Mix (C) \% }\end{array}$ \\
\hline C & 0 & 0.72 & 100 \\
\hline J & 2 & 0.57 & 79.166 \\
\hline K & 3 & 0.46 & 63.88 \\
\hline L & 4 & 0.37 & 51.39 \\
\hline P & 0 & 0.50 & 69.44 \\
\hline R & 2 & 0.35 & 48.61 \\
\hline W & 0 & 0.50 & 69.44 \\
\hline Y & 2 & 0.35 & 48.61 \\
\hline
\end{tabular}

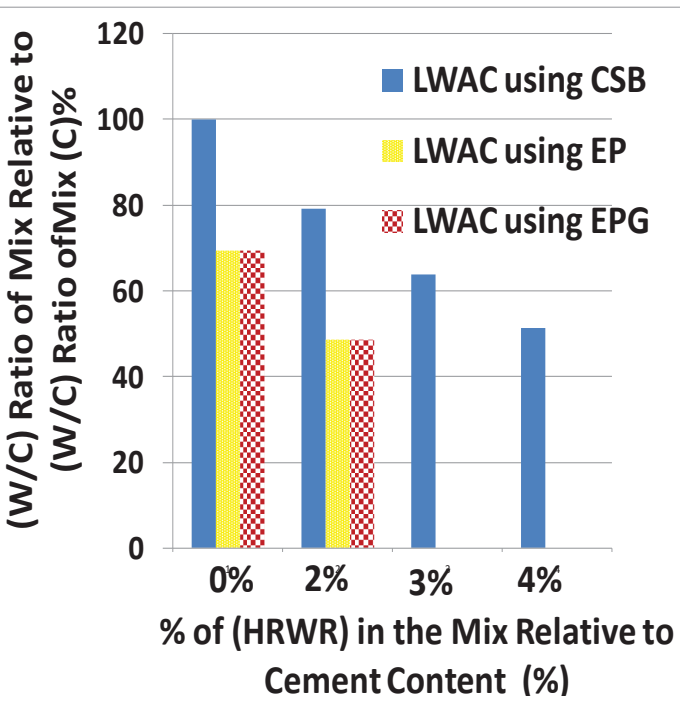

Fig 2 Effect of HRWR on (W/C) Ratio

\subsubsection{Effect of Silica Fume on (W/C) Ratio}

That effect is shown in Table 10 and figure 3. The (W/C) ratio of LWAC using uncoated CSB changes according to the dose of silica fume in the mix, whereas 42,47 , and $52 \%(\mathrm{~W} / \mathrm{C})$ ratios have been indicated for 10,20 , and $30 \%$ silica fume doses of cement by weight as presented in mixes $\mathrm{M}, \mathrm{N}$, and $\mathrm{T}$ respectively, $20 \%$ silica fume of cement by weight increases (W/C) ratio from 0.37 to 0.40 for both LWAC using EP as coarse LWA and for LWAC using EPG as fine LWA as presented in mixes $\mathrm{S}$, and $\mathrm{Z}$ respectively.

Table 10. Effect of Silica Fume on (W/C) Ratio

\begin{tabular}{|c|c|c|c|}
\hline $\begin{array}{c}\text { Mix } \\
\text { ID }\end{array}$ & $\begin{array}{c}\text { \% of } \\
\text { SF }\end{array}$ & $\begin{array}{c}\text { (W/C) } \\
\text { Ratio } \%\end{array}$ & $\begin{array}{c}\text { (W/C) Ratio of the Mix } \\
\text { Relative to Mix (L) \% }\end{array}$ \\
\hline L & 0 & 0.37 & 100 \\
\hline M & 10 & 0.42 & 113.5 \\
\hline N & 20 & 0.47 & 127 \\
\hline T & 30 & 0.52 & 140.54 \\
\hline R & 0 & 0.35 & 108.59 \\
\hline S & 20 & 0.40 & 94.59 \\
\hline Y & 0 & 0.35 & 108.11 \\
\hline$Z$ & 20 & 0.40 & \\
\hline
\end{tabular}




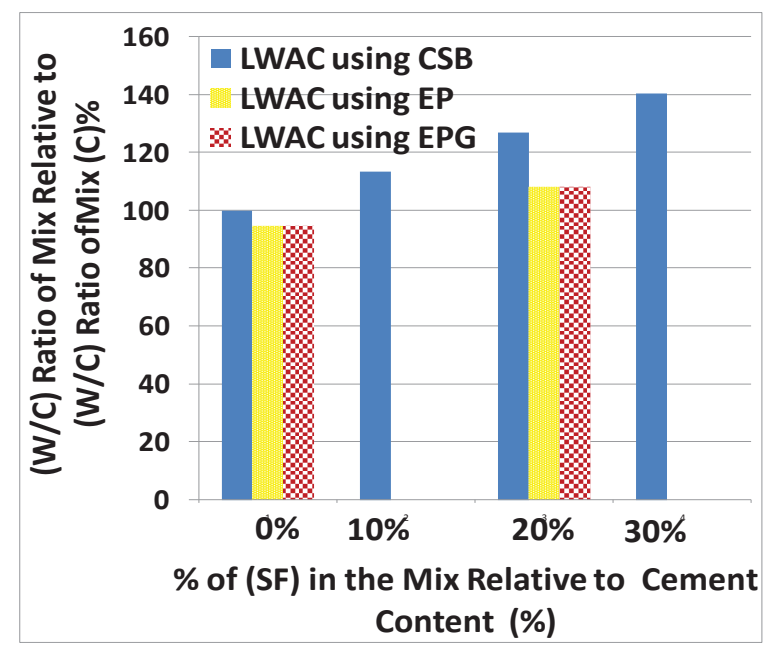

Fig 3 Effect of Silica Fume on (W/C) Ratio

\subsection{Effect of Different Parameters on Unit Weight}

\subsubsection{Effect of Aggregate Type on Unit Weight}

That effect is shown in Table11 and figure 4.Normal weight concrete made with crushed dolomite and sand possessed a unit weight of 2310 $\mathrm{Kg} / \mathrm{m}^{3}$, while using LWA causes extreme reduction in the unit weight, whereas LWAC using uncoated CSB presented in mix (C) indicates unit weight of $1702 \mathrm{Kg} / \mathrm{m}^{3}$, Unit weight of $2029 \mathrm{Kg} / \mathrm{m}^{3}$ for LWAC using coated CSB presented in mix (F), unit weight of $1610 \mathrm{Kg} / \mathrm{m}^{3}$ for LWAC using EP as coarse LWA presented in mix (P) and unit weight of $1868 \mathrm{Kg} / \mathrm{m}^{3}$, for LWAC using EPG as fine LWA presented in mix (W).

Table 11. Effect of Aggregate Type on Unit Weight

\begin{tabular}{|c|c|c|}
\hline $\begin{array}{c}\text { Mix } \\
\text { Id }\end{array}$ & $\begin{array}{c}\text { Unit weight } \\
(\mathrm{Kg} / \mathrm{m} 3)\end{array}$ & $\begin{array}{c}\text { Unit Weight of the Mix Relative } \\
\text { to Unit Weight of Mix (A) \% }\end{array}$ \\
\hline $\mathrm{A}$ & 2310 & 100 \\
\hline $\mathrm{C}$ & 1702 & 73.679 \\
\hline $\mathrm{F}$ & 2029 & 87.835 \\
\hline $\mathrm{P}$ & 1610 & 69.697 \\
\hline $\mathrm{W}$ & 1868 & 80.866 \\
\hline
\end{tabular}

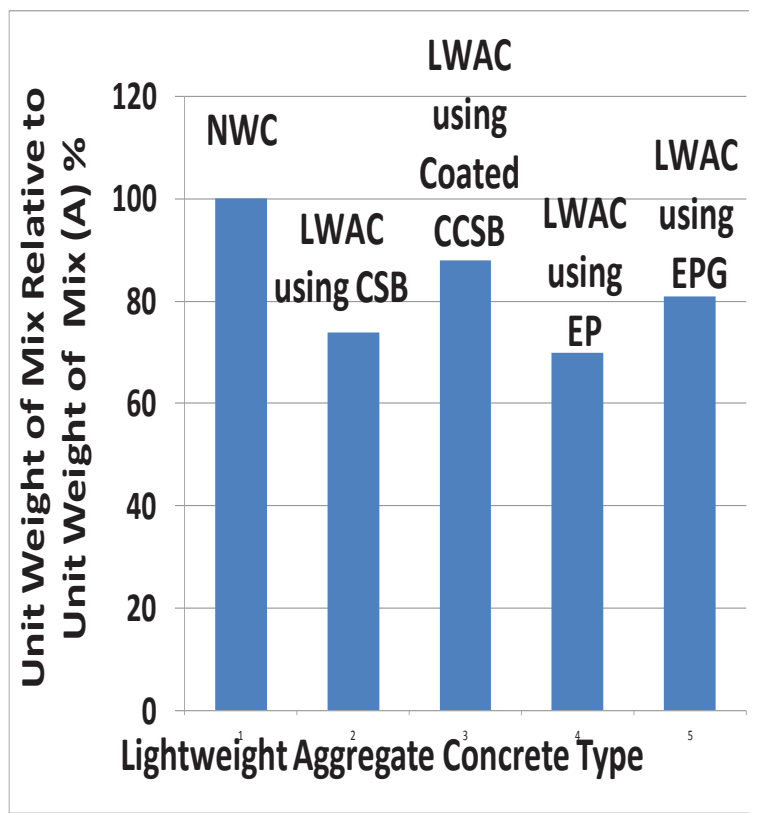

Fig 4Effect of Aggregate Type on Unit Weight

\subsubsection{Effect of Cement Content on Unit Weight}

That effect is shown in Table12 and figure 5,the unit weight of LWAC using uncoated CSB changes according to the used cement content, whereas unit weights of 1661 and $1617 \mathrm{Kg} / \mathrm{m}^{3}$, cement contents have been indicated for 400 and $450 \mathrm{Kg} / \mathrm{m}^{3}$, cement contents as presented in mixes $\mathrm{H}$, and I respectively. Increasing cement content from 350 to $450 \mathrm{Kg} / \mathrm{m}^{3}$ reduces unit weight from 1610 to $1595 \mathrm{Kg} / \mathrm{m}^{3}$, for LWAC using EP as coarse LWA shown in mixes $\mathrm{P}$ and Q respectively and from 1868 to $1833 \mathrm{Kg} / \mathrm{m}^{3}$ for LWAC using EPG as fine LWA presented in mixes $\mathrm{W}$ and $\mathrm{X}$ respectively.

Table 12. Effect of Cement Content on Unit Weight

\begin{tabular}{|c|c|c|c|}
\hline $\begin{array}{c}\text { Mix } \\
\text { Id }\end{array}$ & $\begin{array}{c}\text { Cement } \\
\text { content } \\
(\mathrm{Kg} / \mathrm{m} 3)\end{array}$ & $\begin{array}{c}\text { Unit } \\
\text { Weight } \\
(\mathrm{Kg} / \mathrm{m} 3)\end{array}$ & $\begin{array}{c}\text { Unit Weight of the Mix } \\
\text { relative to Unit Weight of } \\
\text { Mix (C) \% }\end{array}$ \\
\hline C & 350 & 1702 & 100 \\
\hline H & 400 & 1661 & 97.59 \\
\hline I & 450 & 1617 & 95 \\
\hline P & 350 & 1610 & 94.594 \\
\hline Q & 450 & 1595 & 93.713 \\
\hline W & 350 & 1868 & 109.753 \\
\hline X & 450 & $\mathbf{1 8 3 3}$ & 107.697 \\
\hline
\end{tabular}




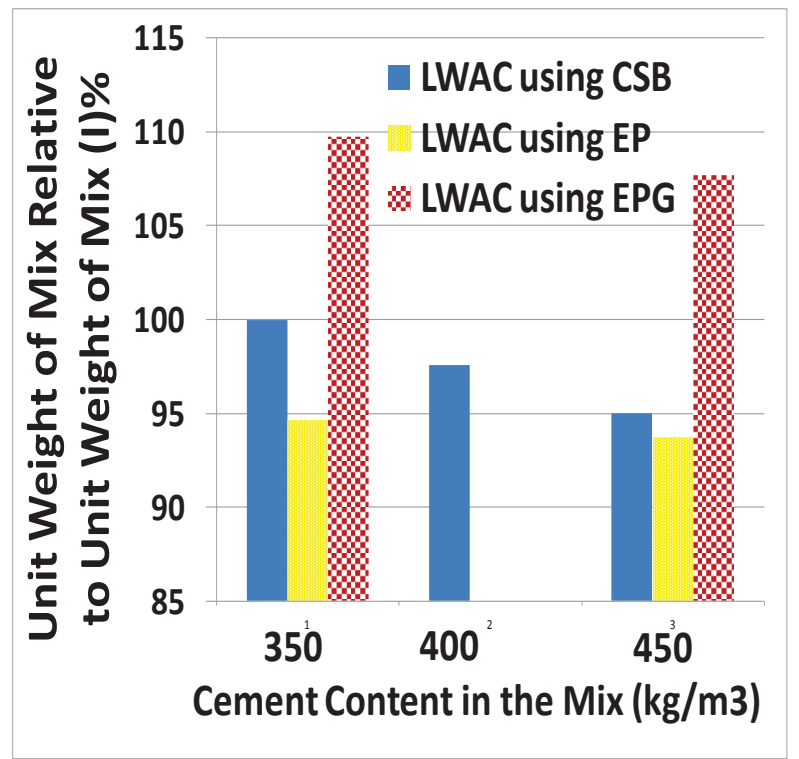

Fig 5 Effect of Cement Content on Unit Weight

\subsubsection{Effect of HRWR on Unit Weight}

That effect is shown in Table13 and figure 6, the unit weight of LWAC using uncoated CSB changes according to the dose of HRWR, whereas 1723, 1853 , and $1825 \mathrm{Kg} / \mathrm{m}^{3}$ unit weights have been indicated for 2, 3, and 4\% HRWR doses of cement by weight as presented in mixes $\mathrm{J}, \mathrm{K}$, and $\mathrm{L}$ respectively. $2 \%$ HRWR of cement by weight reduces unit weight from 1595 to $1650 \mathrm{Kg} / \mathrm{m}^{3}$ for LWAC using EP as coarse LWA as presented in mixes $\mathrm{Q}$ and $\mathrm{R}$ respectively, and from 1833 to $1911 \mathrm{Kg} / \mathrm{m}^{3}$ for LWAC using EPG as fine LWA presented in mixes $\mathrm{X}$ and $\mathrm{Y}$ respectively.

Table 13. Effect of HRWR on Unit Weight

\begin{tabular}{|c|c|c|c|}
\hline $\begin{array}{c}\text { Mix } \\
\text { Id }\end{array}$ & $\begin{array}{c}\text { \%of } \\
\text { HRWR }\end{array}$ & $\begin{array}{c}\text { Unit } \\
\text { Weight } \\
(\mathrm{Kg} / \mathrm{m} 3)\end{array}$ & $\begin{array}{c}\text { Unit Weight of the Mix } \\
\text { relative to Unit Weight } \\
\text { of Mix (I) \% }\end{array}$ \\
\hline I & 0 & 1617 & 100 \\
\hline J & 2 & 1723 & 106.555 \\
\hline K & 3 & 1853 & 114.595 \\
\hline L & 4 & 1878 & 116.141 \\
\hline Q & 0 & 1595 & 98.639 \\
\hline R & 2 & 1650 & 102.041 \\
\hline X & 0 & 1833 & 113.358 \\
\hline Y & 2 & 1911 & 118.182 \\
\hline
\end{tabular}

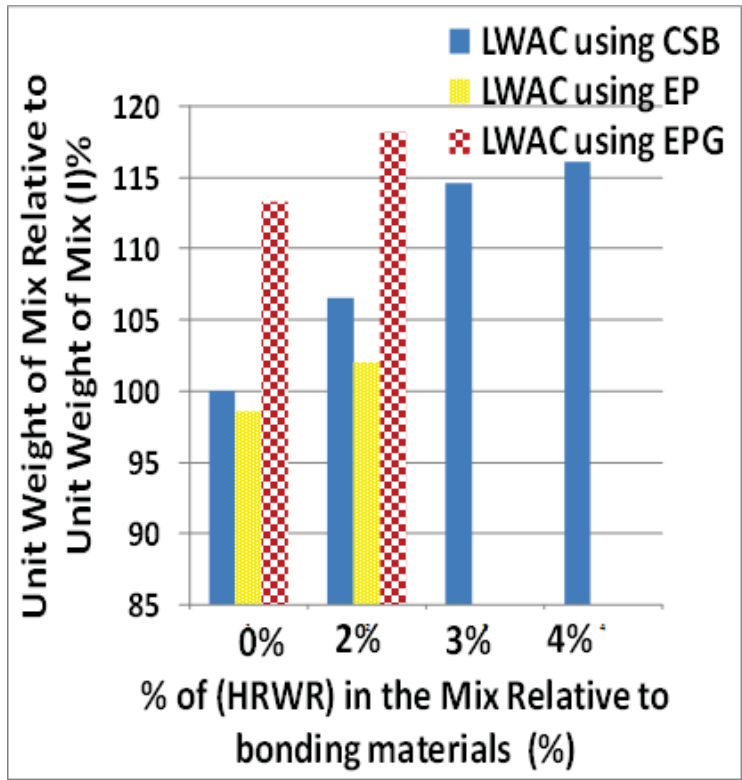

Fig 6 Effect of HRWR on Unit Weight

\subsubsection{Effect of Silica Fume on Unit Weight}

That effect is shown in Table14 and figure 7,the unit weight of LWAC using uncoated CSB changes according to the dose of silica fume in the mix, whereas 1789,1741 , and $1701 \mathrm{Kg} / \mathrm{m}^{3}$ unit weights have been indicated for 10,20, and $30 \%$ silica fume doses of cement by weight as presented in mixes $\mathrm{M}$, $\mathrm{N}$, and $\mathrm{T}$ respectively. $20 \%$ silica fume dose of cement by weight increases the unit weight from 1650 to $1633 \mathrm{Kg} / \mathrm{m}^{3}$ for LWAC using EP as coarse LWA presented in mixes $\mathrm{R}$ and $\mathrm{S}$ respectively and from 1911 to $1877 \mathrm{Kg} / \mathrm{m}^{3}$ for LWAC using EPGas fine LWA as presented in mixes $\mathrm{Y}$ and $\mathrm{Z}$ respectively.

Table 14. Effect of Silica Fume on Unit Weight

\begin{tabular}{|c|c|c|c|}
\hline $\begin{array}{c}\text { Mix } \\
\text { ID }\end{array}$ & $\begin{array}{c}\text { \%of } \\
\text { Filica }\end{array}$ & $\begin{array}{c}\text { Unit weight } \\
(\mathrm{Kg} / \mathrm{m} 3)\end{array}$ & $\begin{array}{c}\text { Unit Weight of the Mix } \\
\text { relative to Unit Weight of } \\
\text { Mix (L) \% }\end{array}$ \\
\hline $\mathrm{L}$ & 0 & 1825 & 100 \\
\hline $\mathrm{M}$ & 10 & 1789 & 98.027 \\
\hline $\mathrm{N}$ & 20 & 1741 & 95.397 \\
\hline $\mathrm{T}$ & 30 & 1701 & 93.205 \\
\hline $\mathrm{R}$ & 0 & 1650 & 90.411 \\
\hline $\mathrm{S}$ & 20 & 1633 & 89.479 \\
\hline $\mathrm{Y}$ & 0 & 1911 & 104.712 \\
\hline $\mathrm{Z}$ & 20 & 1877 & 102.849 \\
\hline
\end{tabular}




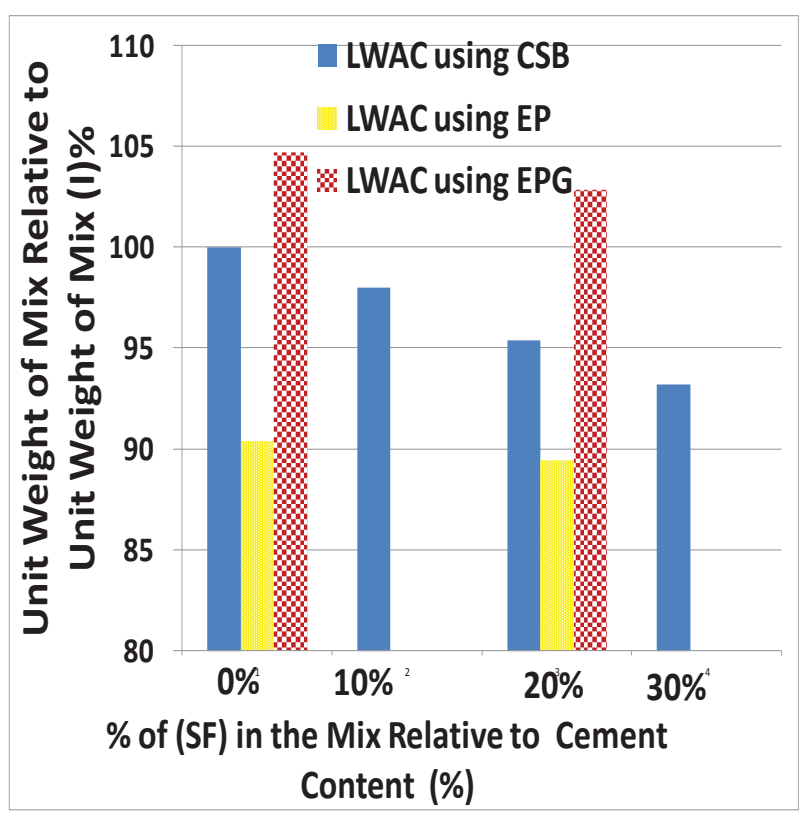

Fig 7 Effect of silica fume on Unit Weight

\subsection{Effect of Different Parameters on Compressive Strength}

\subsubsection{Effect of Aggregate Type on Compressive Strength}

That effect is shown in Table15 and figure 8. The normal weight concrete made with crushed dolomite and sand possessed a compressive strength of 253 $\mathrm{Kg} / \mathrm{cm}^{2}$ presented in mix (A), while using LWA causes extreme reduction in the compressive strength, whereas LWAC using uncoated CSB presented in mix (C) indicates compressive strength of 51.5 $\mathrm{Kg} / \mathrm{cm}^{2}$ and compressive strength of $76 \mathrm{Kg} / \mathrm{cm}^{2}$ for LWAC using coated CSB presented in mix $(\mathrm{F})$.

Compressive strength of $82 \mathrm{Kg} / \mathrm{cm}^{2}$ for LWAC using EP as coarse LWA presented in mix $(\mathrm{P})$ and compressive strength of $125 \mathrm{Kg} / \mathrm{cm}^{2} \mathrm{LWAC}$ using EPG as fine LWA presented in mix (W).

Table 15. Effect of Aggregate and Concrete Type on Compressive Strength

\begin{tabular}{|c|c|c|}
\hline $\begin{array}{c}\text { Mix } \\
\text { Id }\end{array}$ & $\begin{array}{c}\text { compressive } \\
\text { strength } \\
\left(\mathrm{Kg} / \mathrm{cm}^{2}\right)\end{array}$ & $\begin{array}{c}\text { (Compressive Strength of the mix } \\
\text { relative to Compressive Strength of } \\
\text { mix (A) } \%\end{array}$ \\
\hline A & 253 & 100 \\
\hline C & 51.5 & 20.356 \\
\hline F & 76 & 30.039 \\
\hline P & 82 & 32.411 \\
\hline W & 125 & 49.407 \\
\hline
\end{tabular}

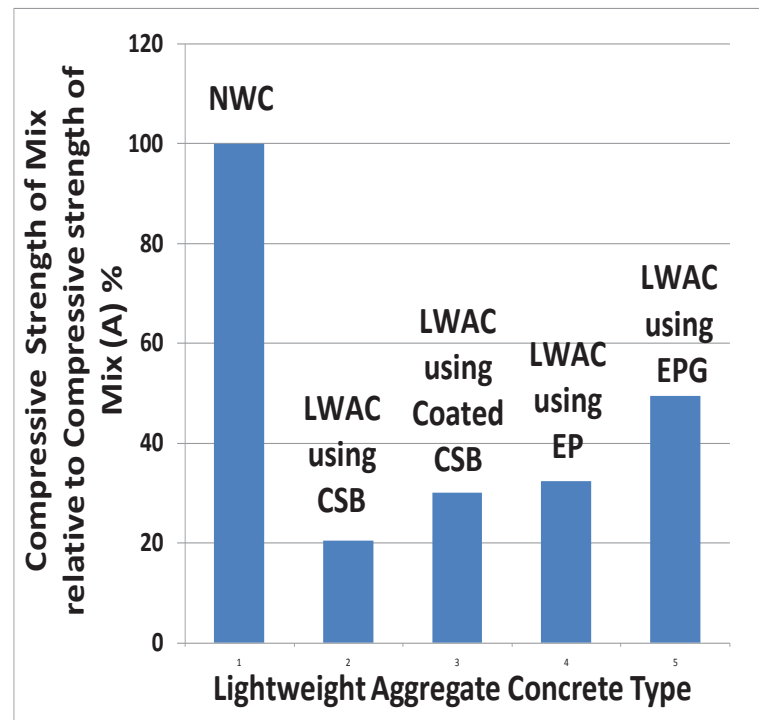

Fig 8. Effect of Aggregate and Concrete Type on Compressive Strength

\subsubsection{Effect of Cement Content on Compressive Strength}

That effect is shown in Table16 and figure 9. The compressive strength of LWAC using uncoated CSB changes according to the cement content, whereas compressive strength values of $59,78 \mathrm{Kg} / \mathrm{cm}^{2}$ have been indicated for 400 and $450 \mathrm{Kg} / \mathrm{m}^{3}$ cement contents as presented in mixes $\mathrm{H}$ and I respectively. Increasing cement content from 350 to $450 \mathrm{Kg} / \mathrm{m}^{3}$ increased compressive strength from 82 to $92 \mathrm{Kg} / \mathrm{cm}^{2}$ for LWAC using EP as coarse LWA presented in mixes $\mathrm{P}$ and $\mathrm{Q}$ respectively, and from 125 to 156 $\mathrm{Kg} / \mathrm{cm}^{2}$ for LWAC using EPG as fine LWA as presented in mixes $\mathrm{W}$ and $\mathrm{X}$ respectively.

Table 16. Effect of Cement Content on Compressive Strength

\begin{tabular}{|c|c|c|c|}
\hline $\begin{array}{c}\text { Mix } \\
\text { Id }\end{array}$ & $\begin{array}{c}\text { Cement } \\
\text { content } \\
\left(\mathrm{Kg} / \mathrm{m}^{3}\right)\end{array}$ & $\begin{array}{c}\text { Compressive } \\
\text { Strength } \\
(\mathrm{Kg} / \mathrm{cm} 2)\end{array}$ & $\begin{array}{c}\text { Compressive Strength of } \\
\text { the mix relative to mix } \\
(\mathrm{C}) \%\end{array}$ \\
\hline $\mathrm{C}$ & 350 & 51.5 & 100 \\
\hline $\mathrm{H}$ & 400 & 59 & 114.563 \\
\hline $\mathrm{I}$ & 450 & 78 & 151.456 \\
\hline $\mathrm{P}$ & 350 & 82 & 159.223 \\
\hline $\mathrm{Q}$ & 450 & 92 & 178.641 \\
\hline $\mathrm{W}$ & 350 & 125 & 242.718 \\
\hline $\mathrm{X}$ & 450 & 156 & 302.913 \\
\hline
\end{tabular}




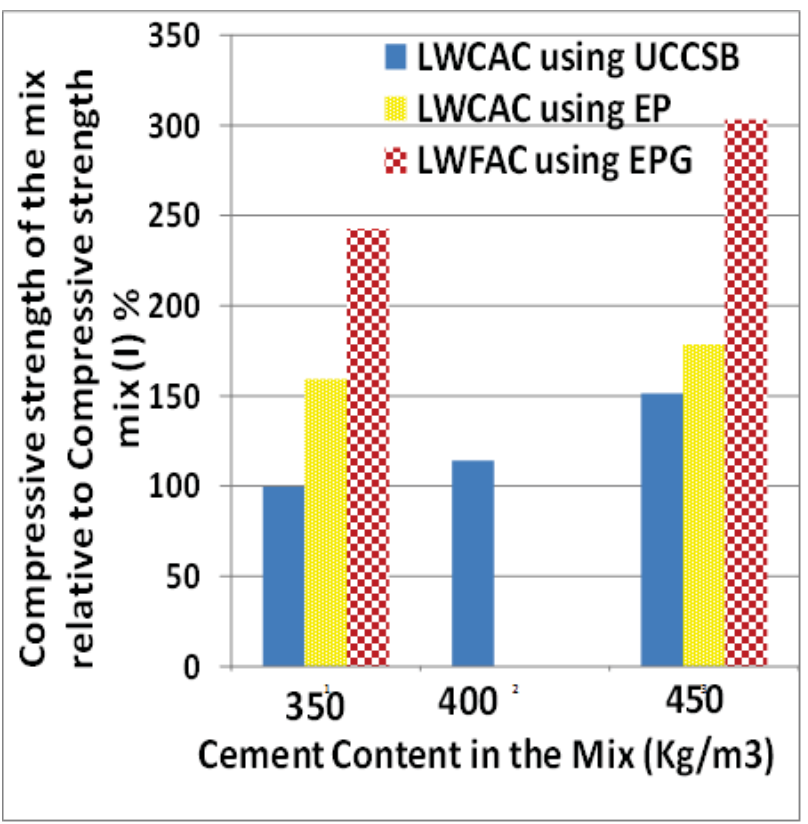

Fig.9 Effect of Cement Content on Compressive Strength

\subsubsection{Effect of HRWR on Compressive Strength}

That effect is shown in Table 17 and figure 10 . HRWR used in LWAC mixes strangely has negligible effect on its compressive strength of as LWA tends to float on the surface of the mix increasing the internal voids in the body of concrete mix. The compressive strength of LWAC using uncoated CSB changes according to the dose of er, whereas 79,82 , and $87 \mathrm{Kg} / \mathrm{cm}^{2}$ compressive strength values have been indicated for 2, 3 and 4\% HRWR doses of cement by weight as presented in mixes $\mathrm{J}$, $\mathrm{K}$, and L respectively $2 \%$ HRWR of cement by weight increased compressive strength from 92 to 98 $\mathrm{Kg} / \mathrm{cm}^{2}$ for LWAC using EP as coarse LWA presented in mixes $\mathrm{Q}$ and $\mathrm{R}$ respectively, and from 156 to $164 \mathrm{Kg} / \mathrm{cm}^{2}$ for LWAC using EPG as fine LWA presented in mixes $\mathrm{X}$ and $\mathrm{Y}$ respectively.

Table 17. Effect of HRWR on Compressive Strength

\begin{tabular}{|c|c|c|c|}
\hline $\begin{array}{c}\text { Mix } \\
\text { Id }\end{array}$ & $\begin{array}{c}\text { \%of } \\
\text { HRWR }\end{array}$ & $\begin{array}{c}\text { Compressive } \\
\text { Strength } \\
\left(\mathrm{Kg} / \mathrm{cm}^{2}\right)\end{array}$ & $\begin{array}{c}\text { Compressive Strength of } \\
\text { the mix relative to mix } \\
(\mathrm{I}) \%\end{array}$ \\
\hline $\mathrm{I}$ & 0 & 78 & 100 \\
\hline $\mathrm{J}$ & 2 & 79 & 101.282 \\
\hline $\mathrm{K}$ & 3 & 82 & 105.128 \\
\hline $\mathrm{L}$ & 4 & 87 & 111.538 \\
\hline $\mathrm{Q}$ & 0 & 92 & 117.949 \\
\hline $\mathrm{R}$ & 2 & 98 & 125.641 \\
\hline $\mathrm{X}$ & 0 & 156 & 200 \\
\hline $\mathrm{Y}$ & 2 & 164 & 210.256 \\
\hline
\end{tabular}

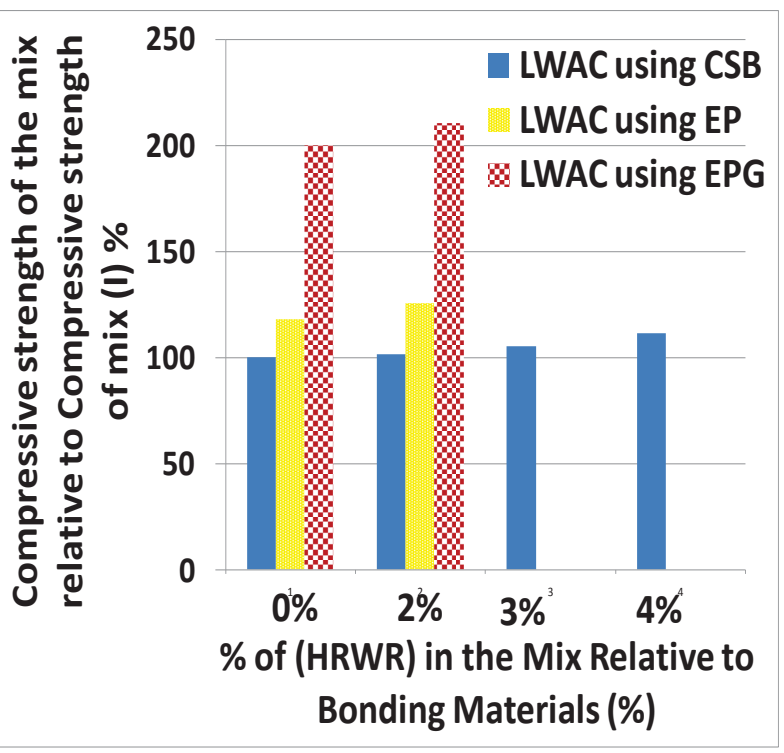

Fig 10 Effect of HRWR on Compressive Strength

\subsubsection{Effect of Silica Fume on Compressive Strength}

That effect is shown in Table18 and figure 11, using silica fume in the mix could increase the compressive strength, the compressive strength of LWAC using uncoated CSB changes according to the dose of silica fume in the mix, whereas 95,117 , and $123 \mathrm{Kg} / \mathrm{cm}^{2}$ compressive strength values have been indicated for 10,20, and 30\% silica fume of cement by weight as presented in mixes $\mathrm{M}, \mathrm{N}$, and $\mathrm{T}$ respectively. $20 \%$ silica fume by weight increased the compressive strength from 98 to $122 \mathrm{Kg} / \mathrm{cm}^{2}$ for LWAC using EP as coarse LWA presented in mixes $\mathrm{R}$ and $\mathrm{S}$ respectively and from 164 to $194 \mathrm{Kg} / \mathrm{cm}^{2}$ for LWAC using EPG as fine LWA presented in mixes $\mathrm{Y}$ and $\mathrm{Z}$ respectively.

Table 18. Effect of Silica Fume on Compressive Strength

\begin{tabular}{|c|c|c|c|}
\hline $\begin{array}{c}\text { Mix } \\
\text { ID }\end{array}$ & $\begin{array}{c}\% \text { of } \\
\text { Silica } \\
\text { Fume }\end{array}$ & $\begin{array}{c}\text { Compressive } \\
\text { Strength } \\
\left(\mathrm{Kg} / \mathrm{cm}^{2}\right)\end{array}$ & $\begin{array}{c}\text { Compressive Strength of } \\
\text { the mix relative to mix (L) } \\
\%\end{array}$ \\
\hline L & 0 & 87 & 100 \\
\hline M & 10 & 95 & 109.195 \\
\hline N & 20 & 117 & 134.483 \\
\hline T & 30 & 123 & 141.379 \\
\hline R & 0 & 98 & 112.644 \\
\hline S & 20 & 122 & 140.229 \\
\hline Y & 0 & 164 & 188.505 \\
\hline Z & 20 & 194 & 222.988 \\
\hline
\end{tabular}




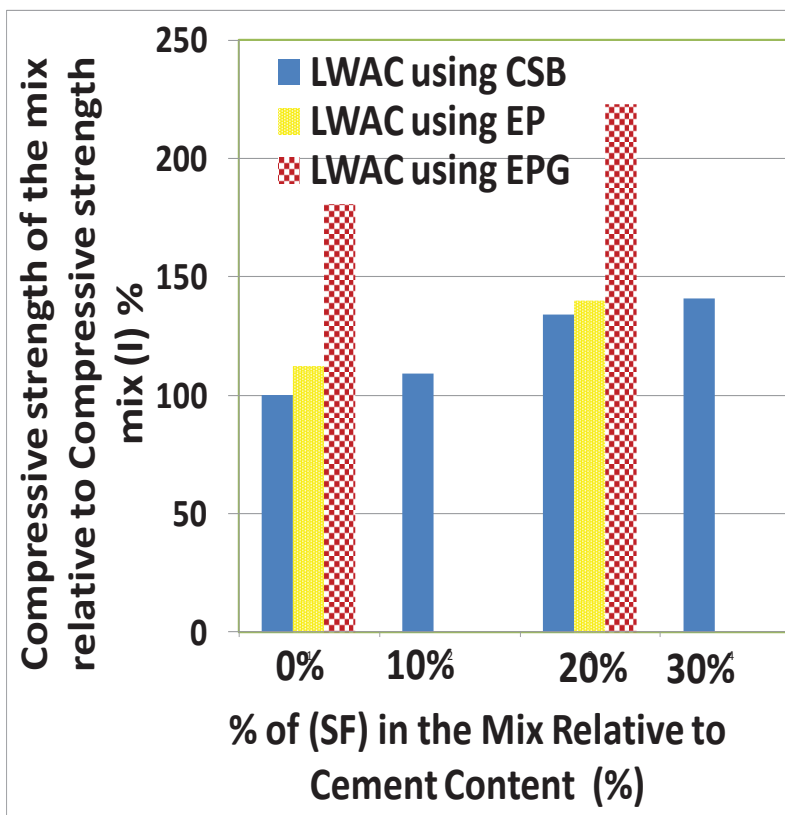

Fig 12 Effect of Silica Fume on Compressive Strength

\section{Conclusion}

The followings have been concluded:

- Using expanded polystyrene as lightweight aggregate is better than crushed and brick because it's impervious material and the produced concrete possesses less water cement ratio, less unit weight, and higher compressive strength.

- All lightweight concrete types reduce the unit weight of the concrete considerably, where as lightweight fine aggregate proves to be better than lightweight coarse aggregate regarding concrete strength.

- Using crushed sand bricks in lightweight aggregate concrete isn't recommended as it highly reduces the concrete strength.

- Silica fume in lightweight concrete mixes improves the compressive strength oflightweight aggregate concrete.

- Using a high range water reducer in lightweight aggregate mixes causes high fluidity in combination with mechanical compaction may lead to aggregate segregation, whereas the lightweight aggregate particles tend to rise to the surface hence causing a non homogenous matrix which fails prematurely under compression.

- It is recommended to use lightweight fine aggregate concrete rather than lightweight coarse aggregate concrete when producing lightweight aggregate concrete.
- It is recommended to use crushed sand brick without surface coating in lightweight aggregate concrete for non-structural applications.

- It is recommended to use lightweight fine aggregate concretes using expanded polystyrene as partial replacement of sand in structural applications such as building construction, due to its low density and reasonable compressive strength.

- It is recommended not to use mechanical vibrators to compact lightweight aggregate concrete especially in case of using high range water reducer and super-plasticizer to prevent float of lightweight aggregate on the surface.

- It is recommended to use high range water reducer and super-plasticizer only in case of using silica fume to avoid increase in water requirements especially in case of using uncoated crushed sand brick.

\section{References}

[1] K. Ganesh Babu, D. Saradhi Babu, "Behaviour of lightweight expanded polystyrene concrete containing silica fume",Cement and Concrete Research, 33(5), 2003 pp. 755-762.

[2] CananTasdemir, OzkanSengul, Mehmet Ali Tasdemir, "A comparative study on the thermal conductivities and mechanical properties of light weight concretes", Energy and Buildings, 151, 2017, pp. 469-475.

[3] Satish Chandra, Leif Berntsson, "Applications of Lightweight Aggregate Concrete", Science, Technology, and applications, 2002. PP. 369-400.

[4] J. Alexandre Bogas, J. Cabaço," Long-term behaviour of concrete produced with recycled lightweight expanded clay aggregate concrete", Construction and Building Materials, 65, 2014, pp. 470-479.

[5] T.W. Bremner, T.A. Holm, "Elastic Compatibility and the Behavior of Concrete", Journal Proceeding, 83(2), 1986, pp. 244-250.

[6] LucynaDomagata, "The Effect of Lightweight Aggregate Water Absorption on the Reduction of Water-cement Ratio in Fresh Concrete", Procedia Engineering,108, 2015, pp. 206-213.

[7] NiyaziUgurKockal, TuranOzturan, "Strength and elastic properties of structural light weight concrete", Materials and Design, 32(4), 2011, pp. 2396-2403.

[8] MetinDavraz, Ali EkremAkdağ, "The Effect of Physical Properties on Thermal Conductivity of Lightweight Aggregate", Procedia Earth and Planetary Science, 15, 2015, PP. 85-92.

[9] M.N Haque H Al-Khaiat, O Kayali, "Strength and durability of lightweight concrete", Cement and Concrete Composites, 26(4), 2004, PP. 307-314.

[10] Kwang-Soo Youm, Jiho Moon, Jae-Young Cho, Jung J. Kim, "Experimental study on strength and durability of lightweight aggregate concrete containing silica fume", Construction and Building Materials, 114, 2016, pp. 517527. 
[11] Adilson Schackow, CarmeaneEffting, Marilena V. Folgueras, SauloGüths, Gabriela A. Mendes," Mechanical and thermal properties of lightweight concretes with vermiculite and EPS using air-entraining agent", Construction and Building Materials, 57, 2014, pp. 190197.

[12] H. Al-Khaiat, M. N. Haque, "Effect of initial curing on early strength and physical properties of a lightweight concrete", Cement and Concrete Research,28(6), 1998, pp. 859-866.

[13] D. Saradhi Babu, T.H. Wee, "Properties of lightweight expanded polystyrene aggregate concretes containing fly ash",Cement and Concrete Research,35(6), 2005, pp. 1218-1223.

[14] FuatKoksal, Osman Gencel, Mehmet Kaya, "Combined effect of silica fume and expanded vermiculite on properties of lightweight mortars at ambient and elevated temperatures Of Inclined Faults", Construction and Building Materials, 88, 2015, pp. 175-187.

[15] M.J. Shannag, "Characteristics of lightweight concrete containing mineral admixtures", Construction and Building Materials, 25(2), 2011, pp. 658-662.

[16] Kim Hung Mo, MohdZamin Jumaat, "Bond properties of lightweight concrete - A review", Construction and Building Materials, 112, 2016, pp. 478-496.

[17] J. Alexandre Bogas, Augusto Gomes, "Compressive strength evaluation of structural lightweight concrete by non-destructive ultrasonic pulse velocity method",Ultrasonics, 53(5), 2013, pp. 962-972. 